\title{
PENDIDIKAN PEMUSTAKA UNTUK MENCERDASAN PEMUSTAKA
}

\author{
Nurhayati Zein \\ Dosen Ilmu Perpustakaan Fak. Adab dan Humaniora \\ IAIN Imam Bonjol Padang \\ e-mail : nurhayatizein@yahoo.co.id
}

\begin{abstract}
College libraries are the heart of universities. This statement has become a commitment for all academicians, but this statement has not been fully enforced by each related party. Like the level of use of library collections, both for library users among the teaching staff (lecturers), students or researchers, even for librarians themselves are those who consider collections that are not touched by users because they are difficult to read, just be put away to the warehouse, in the case that the collections contain information that is of scientific value that is straight, worthy of being used as a scientific benchmark. The visit to the library has decreased, because the user feels unable to read various kinds of information that are already available in the library. Therefore, it is necessary to support user education activities as the main task of the librarian.
\end{abstract}

Keywords: Librarian, Librarian and User Education

\begin{abstract}
Abstrak : Perpustakaan perguruan tinggi adalah jantungnya perguruan tinggi . pernyataan ini sudah menjadi komitmen bagi semua civitas academika,akan tetapi pernyataan ini belum sepenuhnya diberlakukan oleh masing masing pihak terkait.seperti tingkat keterpakaian koleksi perpustakaan, baik itu bagi pemustaka dari kalangan tenaga pengajar ( dosen ), kalangan mahasiswa ataupun dari kalangan peneliti ,bahkan bagi pustakawan itu sendiri ada yang menganggap koleksi koleksi yang kurang dijamah oleh pemustaka karena sulit dibaca disingkirkan saja ke gudang,pada hal koleksi tersebut berisi informasi yang bernilai ilmiah yang lurus,pantas dijadikan tolok ukur ilmiah. Kunjungan ke perpustakaan menjadi menurun, karena pemustaka merasa tidak mampu membaca bermacam macam informasi yang sudah tersedia di perpustakaan.Oleh sebab itu perlu didukung kegiatan user education sebagai tugas pokok pustakawan.
\end{abstract}

Kata kunci : Pemustaka, Pustakawan dan User Education

\section{PENDAHULUAN}

Perpustakaan perguruan tinggi adalah suatu unit kerja yang bertugas sebagai tulang punggung keilmuan ( sumber pembelajaran ) baik dalam proses pendidikan dan pengajaran ataupun dalam proses penelitian termasuk pada proses pengabdian masyarakat. Perpustakaan perguruan tinggi dibangun atas beberapa unsur ,salah satunya adalah koleksi yang digunakan untuk mendukung proses ketiga fungsi perguruan tinggi tersebut yakni tri darma perguruan tinggi . Koleksi tersebut ada yang langsung bisa dibaca tanpa bimbingan bagi yang sudah literat, namun banyak koleksi yang harus diikuti dengan usaha pembimbingan dan petunjuk pencarian informasi. Usaha pembimbingan itu pada saat ini kurang diminati oleh pustakawan 
atau mungkin karena kurang mendapat perhatian dari pihak pihak terkait.

Kemampuan membaca (literasi informasi ) membuat orang menjadi cerdas. Perpustakaan adalah wahana untuk para literat.untuk menjadi tempat belajar mandiri sepanjang hayat. Perpustakaan sengaja menyediakan sumber sumber informasi terpilih yang dapat mengantarkan orang menjadi cerdas dan literat .Pada sumber bacaan tersebut terdapat berbagai informasi dari berbagai bentuk yang perlu dipahami dengan cara ( tehnik) tertentu. Oleh sebab itu pilar pilar yang dapat mengantar kan pemustaka untuk menggunakan tehnik tehnik yang tepat salah satunya adalah user education.

\section{A. Apa yang dimaksud dengan user education?}

Istilah User education berasal dari bahasa Inggeris artinya bimbingan pemakai ,namun seiring dengan perkembangan zaman maka user education dapat diterjemahkan menjadi bimbingan kepada pemustaka. User education ini merupakan tugas pokok bagi pustakawan dari dahulu sampai zaman sekarang ini,bahkan mungkin sampai pada masa yang akan datang,karena semua kemampuan ,keterampilan dan kecakapan bagi setiap manusia bukan didapat dengan sendirinya,akan tetapi memang harus dicapai melalui pelatihan ,bimbingan dan petunjuk.Oleh sebab itu tepat sekali kalau user education ini dilakukan kepada setiap pemustaka di perpustakaan apalagi di perpustakaan perguruan tinggi

User education ini bertujuan untuk memberikan kecakapan dan keterampilan kepada pemustaka tentang cara mencari dan menemukan informasi yang dibutuhkan nya dalam waktu yang relatif singkat dari sumber yang akurat.

User education ini telah menjadi salah satu butir tugas pokok pustakawan yang dapat memberi nilai kumulatif yang bagus bagi pustakawan dalam pengumpulan angka kredit kepustakawanannya, namun diperlukan fasilitas dan dukungan dari atasan langsung yang terkait dalam mengembangkan kemampuan pustakawan itu sendiri.Ada hal yang menarik disimak untuk menggambarkan pengaruh user education ini bagi ilmuwan Indonesia yang pernah belajar ke perguruan tinggi luar negeri.Berikut ini penulis kutip tulisan seorang tokoh ilmuwan yang mendapat kesempatan belajar di perguruan tinggi luar negeri yaitu tulisan yang ditulis oleh Ir.Abdurrahman Saleh ,Dip.Lib,M.Sc dalam bukunya Pengantar Kepustakaan (2009: 1 )

.........ketika saya pertama kali masuk perguruan tinggi di Indonesia,saya tidak pernah diperkenalkan dengan perpustakaan .Seandainya saya sudah diperkenalkan kepada perpustakaan sejak sekolah dasar itu tidak masalah,namun karena di sekolah dasar dan di sekolah lanjutan tidak juga pernah diperkenalkan kepada perpustakaan secara benar,maka saya tidak dapat menggali isi perpustakaan yang ada di kampus 
saya untuk memaksimalkan waktu belajar saya.Inilah salah satu kesalahan yang terjadi di banyak perguruan tinggi Indonesia.,berbeda ketika saya belajar di luar negeri. Saya berkesempatan mendapatkan beasiswa untuk belajar di Inggeris. Minggu pertama ketika dilakukan acara pengenalan kampus ternyata orientasi terhadap perpustakaan memakan waktu yang paling banyak. Tidak heran jika mahasiswa di negara maju dapat memanfaatkan perpustakaan secara maksimal dalam menunjang proses pembelajaran mereka.

Demikian berfungsinya program user education ini dalam membentuk kecerdasan ilmuwan di negara negara yang telah maju user education ini benar benar dapat membantu dan membentuk karakter para pembelajar untuk mencapai karakter literat bagi pemustaka .Karakter yang cenderung membentuk pola pembelajaran mandiri atau pembelajaran sepanjang hayat.

\section{B. Bagaimana Mewujudkan User Education yang Efektif Bagi Pemustaka?}

tinggi tentu akan merancang programnya untuk mencapai target literat untuk pemustaka tersebut dengan seksama Hal penting yang perlu dipikirkan adalah :

1. Kualitas dan kuantitas pustakawan pengelola yang mampu mengemban tugas user education untuk melayani kebutuhan pemustaka dalam aktifitas user education,oleh sebab itu para pustakawan harus selalu menambah ilmu dan kemampuannya dalam menunjang tugas tugas perpustakaan melalui keikut sertaan pada seminar seminar atau diskusi diskusi serta penataran penataran yang diadakan untuk mengembangkan ilmu dan kemampuan bekerja para pustakawan

2. Penyediaan sarana penunjang user education ini seperti menerbitkan buku petunjuk untuk penyelenggaraan administrasi , buku bibliografi dan klasifikasi koleksi untuk menunjuk lokasi informasi, termasuk menerbitkan buku buku indeks untuk mencapai sumber sumber subjek informasi dengan tajuk yang benar

3. Pustakawan tentu harus memiliki keilmuwan bahasa yang memadai dalam memahami informasi yang terdapat pada setiap sumber informasi

4. Penyediaan waktu yang cukup untuk penyelenggaraan user education

Dengan demikian akan dapat terwujud sebagian fungsi perpustakaan perguruan tinggi yakni antara lain yang penting adalah

a) untuk pendidikan artinya untuk memberi kemampuan literat bagi pemustaka agar pemustaka dapat belajar mandiri dalam mengenal dan 


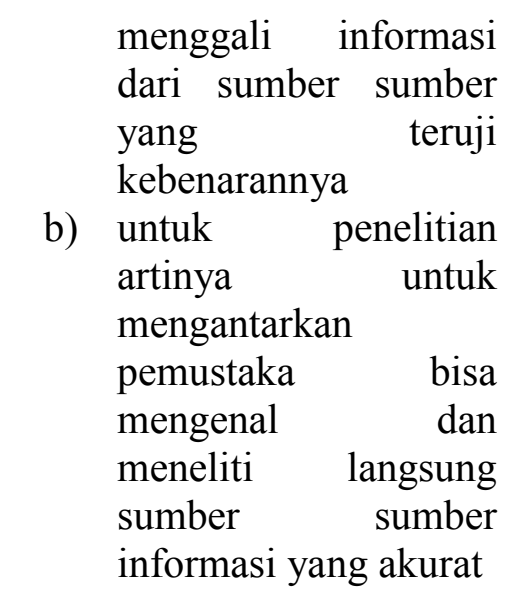

\section{Siapa yang Menyelenggarakan User Education di Perpustakaan Perguruan Tinggi ?}

Tidak semua orang bisa melakukan butir pekerjaan user education Adapun penyelenggara user education pada perpustakaan perguruan tinggi seharusnya dilakukan oleh

1. Pustakawan ahli (dalam hal ini dapat disebut dengan subject spesialis) yakni pustakawan yang menguasai / ahli pada bidang bidang disiplin ilmu dengan sasaran dapat memberi petunjuk tentang cara mencari sumber sumber informasi,minimal dengan membuat/menyusun indeks materi ilmu tersebut yang bisa dijadikan petunjuk.dan dibantu oleh pustakawan referensi

2. Rektor dalam hal ini tentu wakil rektor I yang membidangi akademik dan mutu keilmuan ,mungkin dengan menunjuk orang atau pustakawan yang mampu untuk melakukannya sehingga user education dapat berjalan dengan baik bagi setiap pemustaka yang

membutuhkannya

3. Dibantu oleh jajaran terkait,seperti staf akademik ,staf perlengkapan untuk menerbitkan bahan bahan sarana penunjang dan perlengkapan yang digunakan

Seperti buku buku indeks, buku buku bibliografi, buku buku petunjuk buku pedoman ,katalog dan resensi dan lain lain,yang disusun oleh pustakawan

Kapan dilakukan user education oleh perpustakaan?

User education ini biasanya dilakukan pada:

1. Waktu penerimaan awal anggota baru pemustaka, mereka dikenalkan tentang tekhnik dan cara berurusan ke perpustakaan ,kegiatan ini dapat dilakukan melalui pertemuan dan ceramah atau boleh juga dengan buku panduan , dan sekarang perpustakaan sering memberikannya melalui ranning teks atau video yang diputar pada layar monitor yang ditampilkan di ruang lobby atau di gerbang pintu masuk.

2. Waktu pemustaka butuh bantuan pencarian informasi.Pada kesempatan ini pustakawan dapat melakukan pembimbingan secara massal dalam kelompok kelompok terbatas berpedoman kepada kurikulum fakultas dan jurusan yang ada pada perguruan tinggi tersebut.atau secara individual sesuai kebutuhan . Pada kegiatan ini pustakawan dibantu oleh buku ' petunjuk, 
indeks yang mungkin bisa disusun sendiri oleh pustakawan , bibliografi, yang disusun oleh pustakawan , katalog, abstrak , resensi dan lain lain

\section{KESIMPULAN}

User education adalah tugas pokok pustakawan perguruan tinggi yang harus dilaksanakan dalam proses pengenalan koleksi dengan tujuan membentuk karakter pemustaka menjadi literat (mampu membaca) dan dapat melakukan proses belajar secara mandiri sepanjang hayat.

\section{DAFTAR KEPUSTAKAAN}

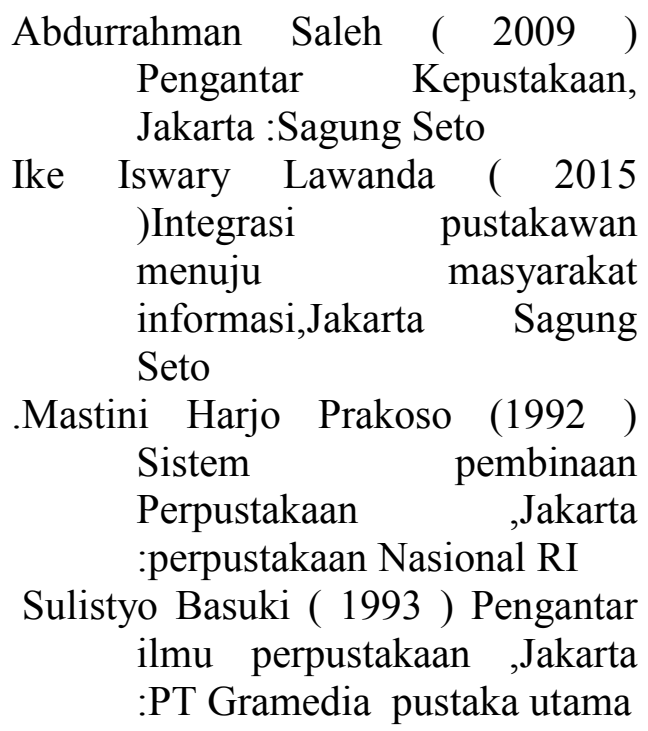

